\title{
THE EFFECT OF CRACKS ON STRESS STATE IN CRANE WHEEL HARD-SURFACE UNDER CONTACT LOADING
}

\author{
Drakče Tanasković, Uroš Tatić, Branislav Đorđević, Simon Sedmak, Aleksandar Sedmak
}

Original scientific paper Shown in this paper are the results of microstructure testing of crane wheels, along with the repair welding procedure performed by hard-surfacing. Repair welding involved the application of a welded layer to the crane wheel, due to the damage that was caused by wear. Detailed analyses, based on the mechanical and chemical properties of the materials used for crane wheels, as well as for repair welding, were performed for the contact between the rail and wheel in real exploitation conditions, as well as by using numerical simulations. Numerical simulations were performed by using the finite element method. For the purpose of the analysis, contact stresses between the wheel and rail were calculated according to Hertz theory. Each of the numerical models was used to perform stress analysis with or without a crack in order to determine crack influence on the crane wheel integrity, and to compare the results with the values obtained theoretically. In addition, the symmetry of the contact area between the wheel and rail was taken into account, i.e. both symmetric and asymmetric contact models were made.

Keywords: crack; FEM; hard-surfacing; integrity; microstructure; rail; wear; wheel

Utjecaj pukotina na stanje naprezanja u navarenom sloju kotača dizalice pri kontaktnom opterećenju

Izvorni znanstveni članak

U ovom su radu prikazani rezultati ispitivanja mikrostrukture kotača dizalice, kao i procedura navarivanja koja je uporabljena za popravak. Reparaturno navarivanje se sastojalo iz dodavanja navarenog sloja na kotač dizalice, koji je prethodno pretrpio oštećenja uslijed habanja. Detaljna analiza kontakta između tračnice i kotača provedena je za realne uvjete opterećenja, kao i pomoću numeričke simulacije, a na osnovu mehaničkih i kemjskih karakteristika materijala uporabljenih za izradu kotača, kao i za reparaturno navarivanje. Numeričke su simulacije provedene primjenom metode konačnih elemenata. Za potrebe analize, vrijednosti kontaktnih naprezanja između kotača dizalice i tračnice određene su prema Hertz-ovoj teoriji. Svi numerički modeli su rabljeni za analizu naprezanja za slučajeve s i bez pukotine u cilju određivanja utjecaja pukotine na integritet kotača dizalice, a dobiveni rezultati su upoređeni s teorijskim vrijednostima. Također, u obzir je uzeta i simetrija kontaktnog područka između kotača i tračnice, tj. napravljeni su numerički modeli sa simetričnom i asimetričnom pozicijom kontakta.

Ključne riječi: kotač; tračnica; habanje; reparaturno navarivanje; pukotina; FEM; integritet; mikrostruktura

\section{Introduction}

Everyday industrial production has a task of achieving highest production rates with the lowest maintenance costs. The task is to reduce costs of both labour and spare parts to the minimum without affecting production process. In the case of steel production one of the most important roles in handling of raw material, as well as with heavy production elements, belongs to cranes. Obviously, their failure can cause major delay in production. Steel mill plant "Železare Smederevo" in Serbia uses a total of 206 cranes from which 127 are technological and 79 are repair cranes. Cranes have lifting capability ranging from $0,5 \mathrm{t}$ up to $170 \mathrm{t}$.

Most common issues with cranes maintenance are caused because of the wear of contact surface of the crane wheels during the exploitation [1]. In case of significant wear or failure, wheels are repaired and reused [2]. Repair of contact surface is performed by surface welding. During the average production cycle in Steel mill plant "Železare Smederevo" between 20 and 25 wheels are repaired each month. With increase in production an increase in wheel repair can be noted as well. The main problem of repaired wheels is reflected in occurrence of cracks in welded layers, being typical problem in hard surfacing $[3 \div 5]$. One of the key issues here is base metal itself, namely ferrite-pearlite steel with relatively high content of carbon, being susceptible to cracking during unfavourable thermal stresses, which are unavoidable during hard surfacing.

Because of high production rates and short time schedule there are cases where a repaired wheel with a crack must be used. The aim of this paper is to provide insight into the crack behaviour and the lifespan of repaired wheels with and without the cracks, as briefly analysed in [6].

\section{Wheel design and materials}

Depending on the application and working conditions, different geometry of wheels can be distinguished:

- Wheel without rims,

- Wheel with a single rim,

- Wheel with two rims,

as well as the two main types of the contact surface:

- Conical,

- Cylindrical.

Contact surface diameters are ranging from $\varnothing 315 \mathrm{~mm}$ to $\varnothing 800 \mathrm{~mm}$.

Examples of the different geometries as well as contact surfaces of wheels can be seen in Fig. 1 .

Wheels are manufactured either by forging or casting. Materials used were C11G1C, C14G1C, C45, C45E, C45G for forging, while GS255JRN, GS295JRN, G34CrMo4 along with adequate machine and thermal processing were used for casting. It must be noted that the hardness of the contact surface for a new wheel ranges between 38 and $40 \mathrm{HRc}$. 


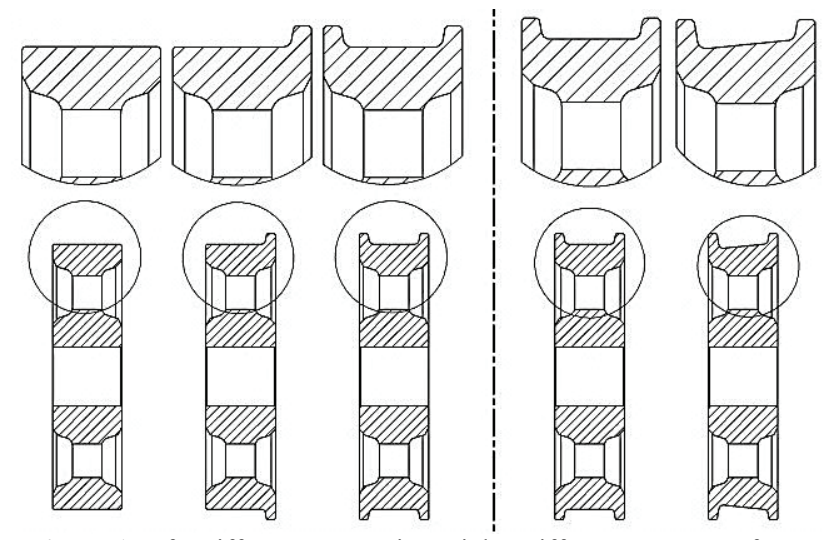

Figure 1 Left: Different geometries; Right: Different contact surfaces

Most commonly used wheel type in Steel mill facility "Železara Smederevo" is with two rims and cylindrical contact surface, as shown in Fig. 2. Test and simulations shown in this paper were obtained on this type of wheel.

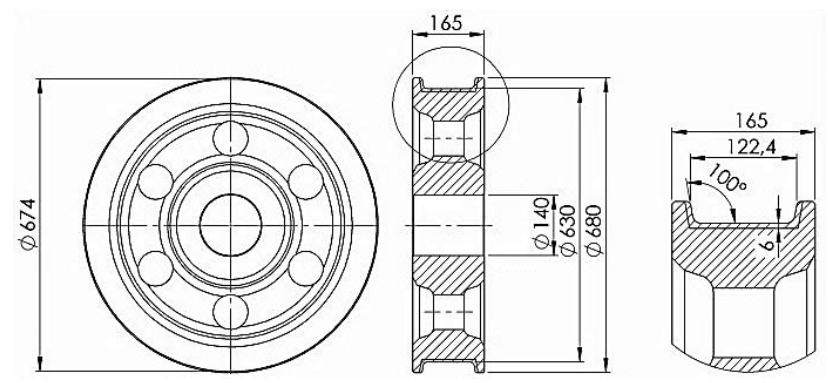

Figure 2 Geometry of the most commonly used wheel type in Steel mill facility "Železara Smederevo"

Contact surface diameter is $\varnothing 630 \mathrm{~mm}$ with outer rim diameter $\varnothing 680 \mathrm{~mm}$. Rims are set under the angle of $100^{\circ}$. Width of the wheels is $165 \mathrm{~mm}$. Wheels are made with six symmetrically spaced holes used to reduce weight. Hole for the axis has a diameter of $140 \mathrm{~mm}$. Repaired welded layer with a thickness of $6 \mathrm{~mm}$ can be seen at the contact surface area. Geometry of the rail S49 (DIN 536 part 1, TU U 14-2-1230-99) with enlarged contact area can be seen in Fig. 3[7].
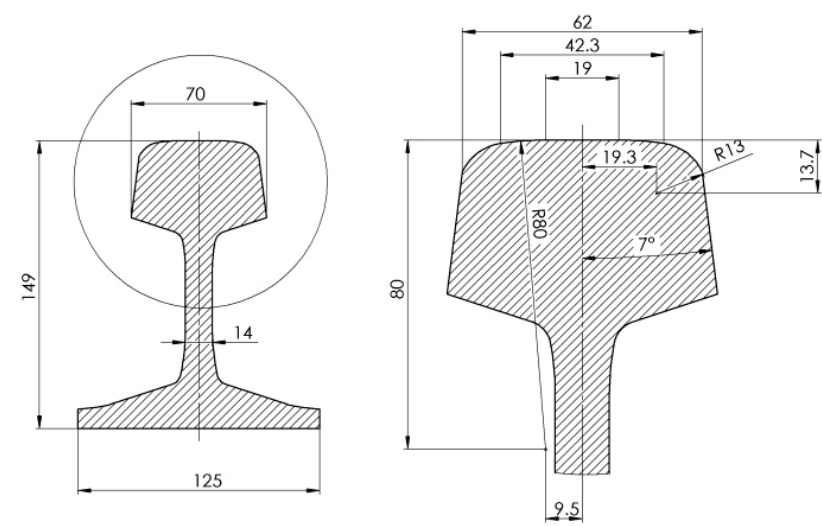

Figure 3 Geometry of the rail

\section{Wheel wear and damage}

There are several different scenarios of the wheel damage that can occur during a lifespan. Over the last years where the production rate has significantly increased, an increase in wheel replacement has been also noted. The most common reason for replacement is the wear of the rim. It is defined by the local regulations that in a case when rim thickness is reduced to $10 \mathrm{~mm}$ or less the wheel must be replaced immediately. Rim wear or even breakage is responsible for almost $40 \%$ of all failures. Fig. 4 represents a diagram with all of the most common failures defined in the percentage.

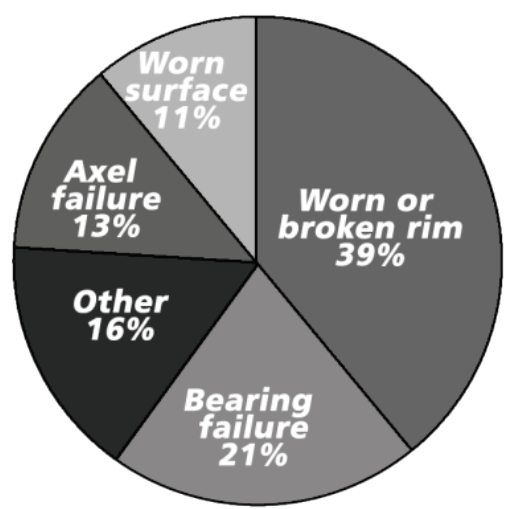

Figure 4 Failure types shown in percentage

According to the local regulations in the case of a contact surface diameter reduction bigger than $5 \mathrm{~mm}$, wheel must be replaced. However, while surface wear is responsible only for $11 \%$ of the wheel replacements, it is the most commonly performed wheel reparation procedure.

Examples of surface and rim wear as well as the rim breakage that has occurred during the wheel exploitation can be seen in Fig. 5 and Fig. 6.

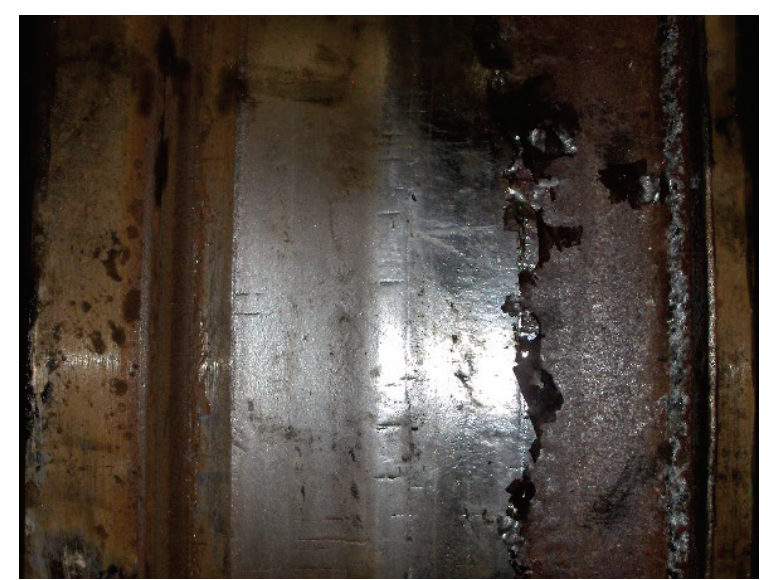

Figure 5 Contact surface and rim wear during the wheel exploitation

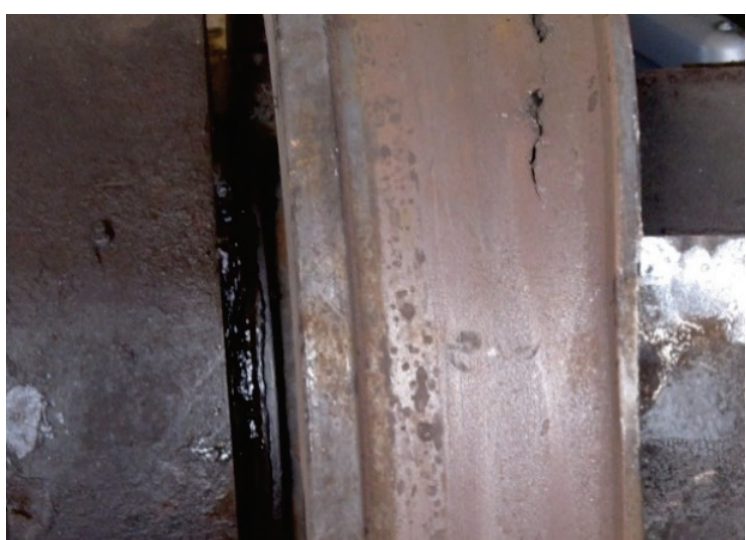

Figure 6 Rim wear and breakage during the wheel exploitation 
Increase in loading to the maximal lifting capabilities of each crane causes the contact loadings between the wheel and rail to increase as well. This typically results in general damage from wear to fatigue. Unlike the slow process of wear, fatigue causes cracks on contact areas of wheels, along with loss of material. Experiments have proven that an increase in surface hardness improves its wear resistance $[8,9]$. However, if this hardness "goes" deeper into the wheel rim, it will actually increase the probability of its failure, leading to wheel damage.

Core toughness below the hard surface area contributes to chipping of material from the wheel contact surface, due to the fact that the tough core absorbs the stresses caused by incorrectly levelled rails. These stresses can be transferred to the rim, leading to damage and fracture. Therefore, stress analysis of crane wheel is essential, in order to assess its integrity and life, as shown in $[10 \div 12]$.

\section{$4 \quad$ Repair welding procedure}

Local procedures of wheel repairing for cranes state the operations should be performed in the following order:

Wheel normalization represents first step in the process. All of the wheels must be put to process of normalization regardless of them being previously repaired. By doing this influence of the residual stresses is reduced.

It is of great importance to perform pre-treating of the contact surface diameter. If the rim diameter is within \pm 5 $\mathrm{mm}$ of the nominal measure according to drawings, it should not be treated. In case the rim diameter is more than $5 \mathrm{~mm}$ below the nominal measure, it should be pretreated until the first clean measurement (perfectly round surface). This is performed in $6 \mathrm{~mm}$ increments.

In the next phase measuring of the pre-treated wheel according to the sketch must be performed to ensure adequate geometry required for further process. Pre-heating of the wheel to a temperature $200{ }^{\circ} \mathrm{C}$ to $220^{\circ} \mathrm{C}$ is necessary. Contact area and rims should be welded using a wire, followed by 3 layers welding procedure. During welding, temperature should be maintained between 320 ${ }^{\circ} \mathrm{C}$ and $450{ }^{\circ} \mathrm{C}$.

Wheel annealing is performed in furnace where it is heated for 2 hours to a temperature of $540{ }^{\circ} \mathrm{C}$. The furnace is cooled down to a temperature of $200{ }^{\circ} \mathrm{C}$. It should be noted that the speed of cooling and heating should be $50^{\circ} \mathrm{C} / \mathrm{h}$.

Contact surface and rim should be machined to match the drawing measures. Edges should be treated and threads should be cut on both fronts of the wheel.

The most common disadvantages of repaired wheels are low hardness and the occurrence of transverse surface cracks in the rim and contact surfaces. Wheels with low hardness are subjected to repeated heat treatment, while the wheels with cracks are discarded. The reasons for the expulsion of wheels with cracks are uncertainty of their characteristics and integrity.

In the newly built, as well as the repaired wheels cracks may occur during exploitation as a result of concentration of stress and fatigue. Occurrence of crack initiation represents key parameter for replacement of these wheels.
In practice it has been shown that despite the strict control after repair welding process, wheels with the initial crack can be found in exploitation [14]. The origin of errors can be multiple: selection of filler material and of surfacing technology, human error, regime of thermal treatment etc. Work life of the wheels depends on crack growth from initial stages, whereas development of cracks depends on the fatigue threshold.

\subsection{Welding procedure}

As defined by procedure, contact area and rims side walls were welded using a wire, followed by 3 welded layers. Submerged Arc welding Flux procedure was used for welding. Materials used for welding procedure were WLDC-9 for an intermediate "puffer" layer (for bridging the difference in material properties of base metal and welded layer) and WLDC-12 for hard-surfacing. Wire materials are manufactured by Weldclad COREWIRE HARDFACING CONSUMABLES Company [13]. Before welding process, wheel was subjected to preheating. Two layers of hard surfacing were welded.

Chemical composition of base material and both additional materials can be seen in Tab. 1 .

Table 1 Chemical composition of materials

\begin{tabular}{|l|c|c|c|c|c|}
\hline $\begin{array}{c}\text { Additional } \\
\text { material }\end{array}$ & $\mathrm{C} \%$ & $\mathrm{Si} \%$ & $\mathrm{Mn} \%$ & $\mathrm{Cr} \%$ & $\mathrm{Mo} \%$ \\
\hline GS-42CrMo4 & $0,38 \div 0,45$ & 0,6 & $0,6 \div 1$ & $0,8 \div 1,2$ & 0,25 \\
\hline WLDC-9 & 0,1 & 0,5 & 1 & 0,1 & 0,5 \\
\hline WLDC-12 & 0,15 & 0,5 & 1 & 3,5 & - \\
\hline
\end{tabular}

Characteristics of welding process for both materials are shown in Tab. 2, while mechanical characteristics of hard-surfacing layer can be seen in Tab. 3 .

Table 2 The parameters of the welding processes

\begin{tabular}{|c|c|c|c|}
\hline Layer number & $\begin{array}{c}\text { Additional } \\
\text { material }\end{array}$ & Current (A) & Voltage (V) \\
\hline 1 & WLDC-9 & 300 & 28 \\
\hline $2 \div 3$ & WLDC-12 & 300 & 28 \\
\hline
\end{tabular}

Table 3 Mechanical characteristics of hard-surfacing layer (second and

\begin{tabular}{|c|c|c|c|c|c|}
\hline $\begin{array}{c}\text { Additional } \\
\text { material }\end{array}$ & $\begin{array}{c}R_{\mathrm{m}} \\
(\mathrm{MPa})\end{array}$ & $\begin{array}{c}R_{\mathrm{p} 0,2} \\
(\mathrm{MPa})\end{array}$ & $\begin{array}{c}A_{5} \\
(-)\end{array}$ & $\begin{array}{c}A_{\mathrm{v}} \\
(\mathrm{J})\end{array}$ & Hardness \\
\hline WLDC-12 & 940 & 810 & 15 & 13 & 40 HRc \\
\hline
\end{tabular}

The initial temperature for the second and third welded layer is higher than the preheating temperature and therefore, during the welding process of these layers, temperature should be frequently controlled and pauses should be made to avoid exceeding the maximum allowable temperature, which causes hot cracking.

After welding, wheel was subjected to annealing. Appearance of repaired wheel after welding procedure can be seen in Fig. 7.

\subsection{Metallographic analysis of sheets defect}

In order to examine the microstructure of welded layer, samples in the shape of sheet were tested. Welding procedure of tested samples was performed with the same parameters as the real wheel. The microstructure of the 
base material is a ferrite-pearlite. Macro appearance of sample can be seen in Fig. 8 .

Microstructure of the sample can be seen in Fig. 9. Martensite structure in both welded layers can be observed. Martensite structure has very high wear resistance. It is used to solve the problem of wear due to friction of metal on metal or general wear and tear caused by friction and impacts, $[11,13]$.

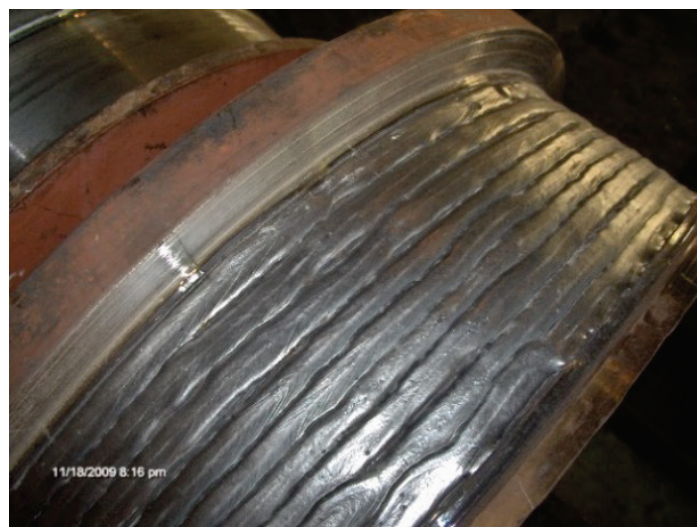

Figure 7 Repaired wheel after welding procedure

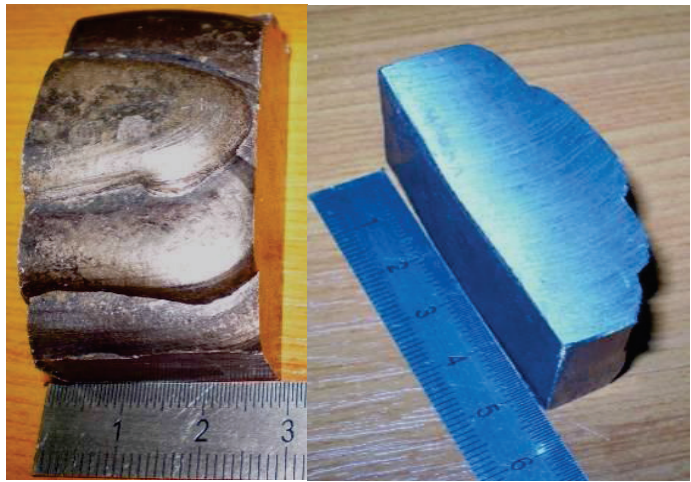

Figure 8 Macro appearance of sample

\section{Wheel load}

Wheels with a diameter of $630 \mathrm{~mm}$ and flat contact surface which move along the type $\mathrm{S} 49$ rail have maximum allowed load of $200 \mathrm{kN}$. It must be noted that the span of rails ranges between $21,5 \mathrm{~m}$ and $32 \mathrm{~m}$.

During the contact between two cylindrical machine parts with parallel generatrices, the contact area is shaped like a narrow rectangle with width of $2 e$ and length $l$. Assuming that the curve radii of these cylinders are $\rho_{1}$ and $\rho_{2}$, made of a material with the Poisson's ratio of $v=0,3$ and elasticity modules of $E_{1}$ and $E_{2}$, then the contact rectangle width is equal to:

$$
2 e=3,04 \cdot \sqrt{\frac{F \cdot \rho}{E \cdot I}},
$$

$E=\frac{2 E_{1} E_{2}}{E_{1}+E_{2}}-$ Equivalent elasticity module,

$\rho=\frac{\rho_{1} \rho_{2}}{\rho_{1}+\rho_{2}}-$ Equivalent curve radius.

According to Hertz's theory of contact stresses, contact stress between wheel and rail (flat surface cylinder) is:

$$
p_{\text {max }}=\frac{4}{\pi} \cdot p_{\text {av }}=0,418 \cdot \sqrt{\frac{F \cdot E}{\rho \cdot I}}=1082 \mathrm{MPa} .
$$

In case of sphere contact, i.e. between a cylinder and a flat surface (wheel and rail), $\rho_{2}=\infty$ is adopted in above relations, resulting in a reduced curve radius, $\rho=\rho_{1}$.

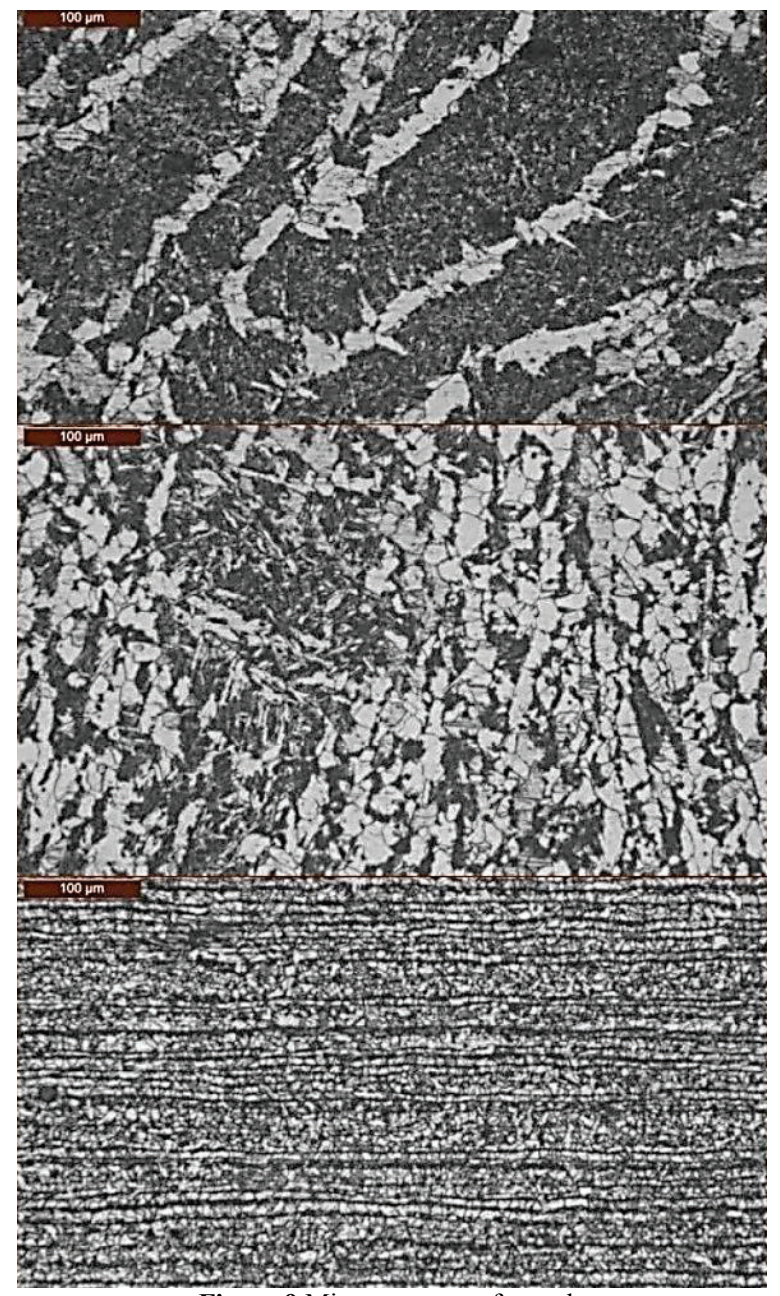

Figure 9 Microstructure of sample

\section{Numerical simulation by the finite element method}

Geometry of the rail and wheel is relatively simple, but contact between rail and wheel represents a complex part to be modelled because of curvature in surface and different material sections. Approximations in a form of removing of the small radii on both models, as well as removing of the holes on the side wall, were performed. All radii that were excluded from the model were positioned far from the contact area, and did not have any significant influence on the model integrity.

In order to evaluate stress strain distribution caused by the contact, four separate models were developed. First model was made with assumption that a contact was ideal, i.e. that the wheel and the rail were symmetrical, Fig. 10. This model was denoted as symmetric loading without a crack.

Second developed model represents a case where a wheel has been moved to the side, and contact is present on side surfaces of wheel and rail. As a result of this asymmetric position, and contact between wheel rim and 
rail, there is no initial contact between top of the rail and wheel i.e. gap is present between top surfaces of the wheel and rail. This model was denoted as asymmetric loading without a crack and can be seen in Fig. 10.

Third model used for evaluation was positioned as a symmetric loading but with a symmetrically positioned crack in the contact area. This model was denoted as symmetric loading with a crack and can be seen in Fig. 10 .

The fourth model developed was based on asymmetric loading with an asymmetrically positioned crack in the transition area between the wheel rim and contact surface. This model was denoted as asymmetric loading with a crack and can be seen in Fig. 10.

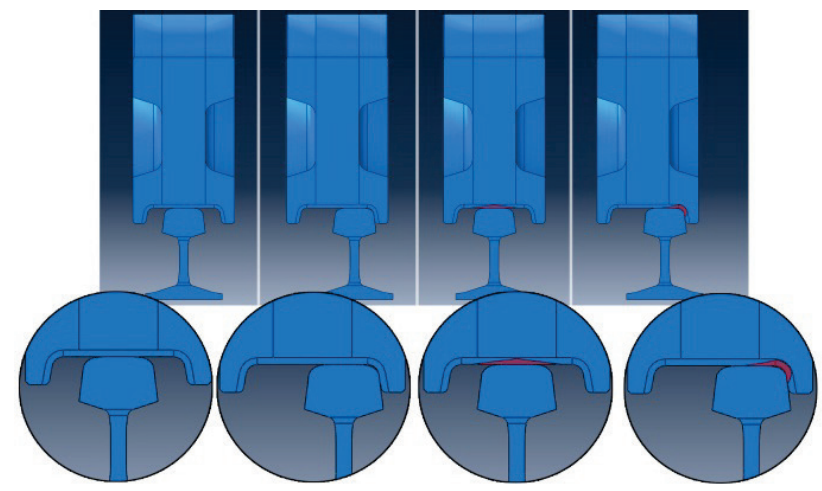

Figure 10 Different models used for simulations (left to right); symmetric loading without a crack; asymmetric loading without a crack; symmetric loading with a crack; asymmetric loading with a crack.

Detailed dimensions and sketches of predefined cracks on models with symmetric loading and asymmetric loading with a crack can be seen in Fig. 11 .
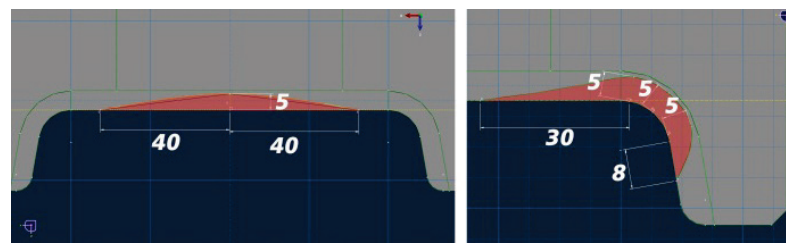

Figure 11 Sketches used to define cracks geometry

All models were created as quarters of a wheel, since stress strain distribution is expected only in the area between the axis and contact with the rail. Length of the rail was reduced to $150 \mathrm{~mm}$ which ensured enough length to provide adequate behaviour outside the direct contact area.

Loading on the wheel was defined as concentrated force. In order to ensure even distribution, two equal forces with a value of $100 \mathrm{kN}$ each were applied. Forces were positioned along the bottom line of an axis opening at a distance of $47,5 \mathrm{~mm}$ from the side of the wheel.

Loadings and boundary conditions that were applied to all models can be seen in Fig. 12. Support on a bottom side of the rail was used to restrict the position of the whole assembly and to simulate working conditions. Additional restriction to lateral movement and rotation was added on to side surfaces of axis opening (green area). Displacement restriction in the axial direction of the rail was also introduced (red area). Please note that although boundary conditions and loads were the same for all models, with only difference in the mutual position of the wheel and rail and geometry of the crack, in Fig. 12 only symmetric loading without a crack and symmetric loading with a crack is shown. In the case of all models with a crack, crack area displacement was not restricted in the axial direction.

Symmetric models were defined with only the contact between the top of the rail and the rim, while asymmetric models were defined with initial contact between the sidewalls of the rim and rail and a contact between the top of the rail and the rim that was a result of the applied loading.

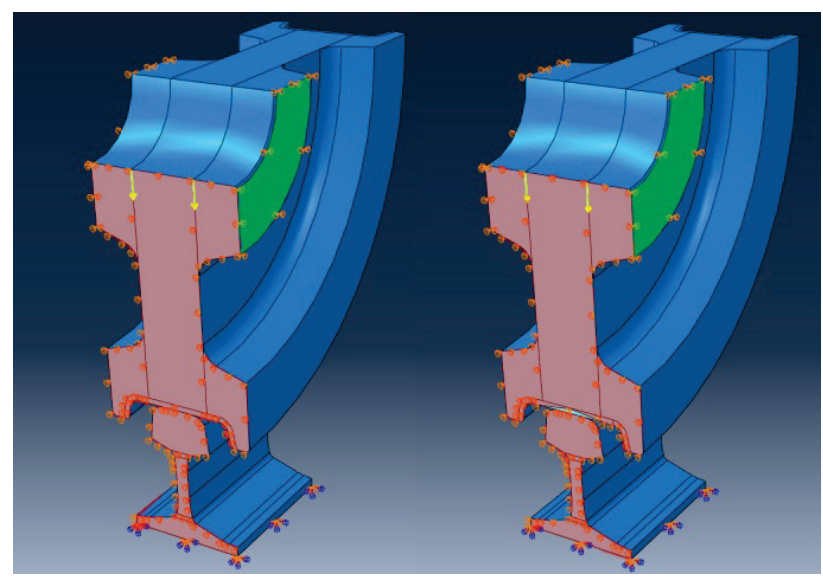

Figure 12 Left: Loads and boundary conditions for symmetric loading without a crack; Right: Loads and boundary conditions for symmetric loading with a crack

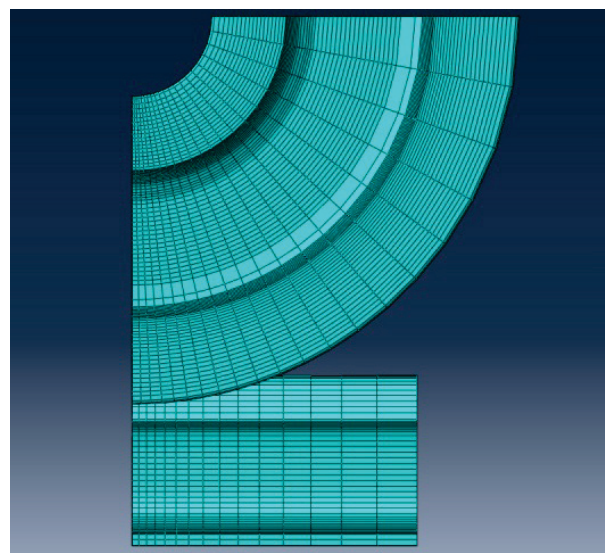

Figure 13 The finite element mesh

All models were meshed with the use of C3D8R elements, 8-node linear elements with reduced integration. Element size was reduced towards the contact area in both wheel and rail in order to ensure adequate results. Example of the mesh is shown in Fig. 13.

\section{Results}

Numerical simulations performed in this paper have shown that the stress is concentrated around the contact area for all of the models, as was expected. Different values of stress can be observed throughout the different material sections. Upper Fig. 14 represents a Von Misses stress field for a symmetric loading without a crack. Stress value in the contact area is ranging between 510 $\mathrm{MPa}$ and $530 \mathrm{MPa}$, while in the welded area it reaches value of $849 \mathrm{MPa}$.

In the case of symmetric loading with a crack, shown in lower Fig. 14, an increase in stress can be observed 
throughout the welded area. Presence of the crack in the model has resulted in the stress values in contact area ranging between $715 \mathrm{MPa}$ and $1013 \mathrm{MPa}$. Increased deformation of the contact area has resulted in a decrease of stress in the top of the welded area to $770 \mathrm{MPa}$.

Stress field for asymmetric loading without a crack is shown in upper Fig. 15. Asymmetric position of the wheel and the rail has resulted in the appearance of the lateral forces causing increase in both wheel and rail.

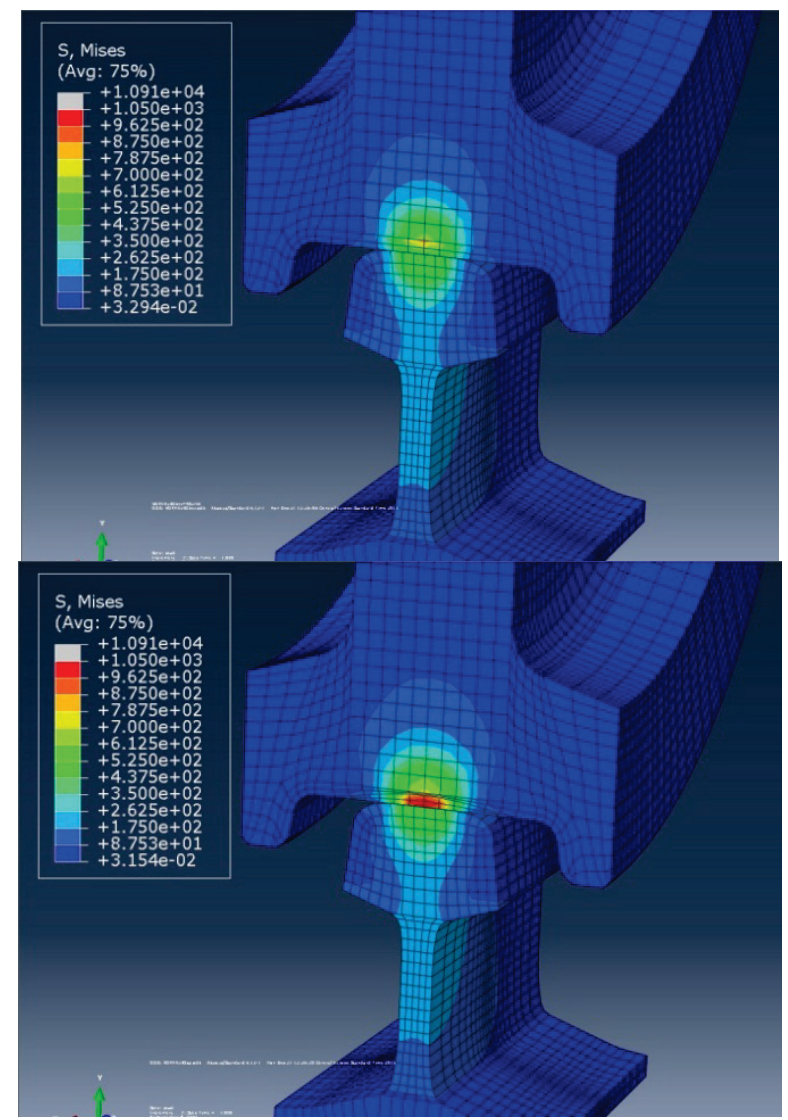

Figure 14 Upper, Von Misses stresses for symmetric loading without a crack; lower, Von Misses stresses for symmetric loading with a crack

Stress value in the contact area is ranging between $870 \mathrm{MPa}$ and $970 \mathrm{MPa}$, while in the welded area it reaches value of $1030 \mathrm{MPa}$. Case of the asymmetric loading with a crack is shown in the lower Fig. 15. The influence of the crack on the contact area has resulted in stress dissipation over a larger area. Because of all the mentioned reasons, stress values within the wheel have dissipated over a larger area with the value of around 700 $\mathrm{MPa}$, while stress within the rail has increased to a value of $1050 \mathrm{MPa}$.

Displayed stress filed for all models is restricted to $1050 \mathrm{MPa}$ since the higher values are result of the loading and are present in the contact area. Stress field in the concentrated loading area was neglected.

As it can be seen from the figures, the stress in the welded layer of the crane wheels has similar values to the values within the rail in case of symmetric contact area, for both symmetric and asymmetric cases, without the crack. This is a result of similar mechanical properties of the materials used.

As for models with cracks, there is a difference in stress levels between the welded layer and the rail. In the case of symmetric model, the crack is positioned directly in the contact zone. As a result, the stress values within the welded layer are much higher than the values within the rail. On the other hand, the crack in the asymmetric model is only slightly positioned within the and due to this, stress values in the rail are higher than those within the welded layer, because of the geometry. In the contact area, there is no stress concentration in the welded layer, due to this position of the crack.

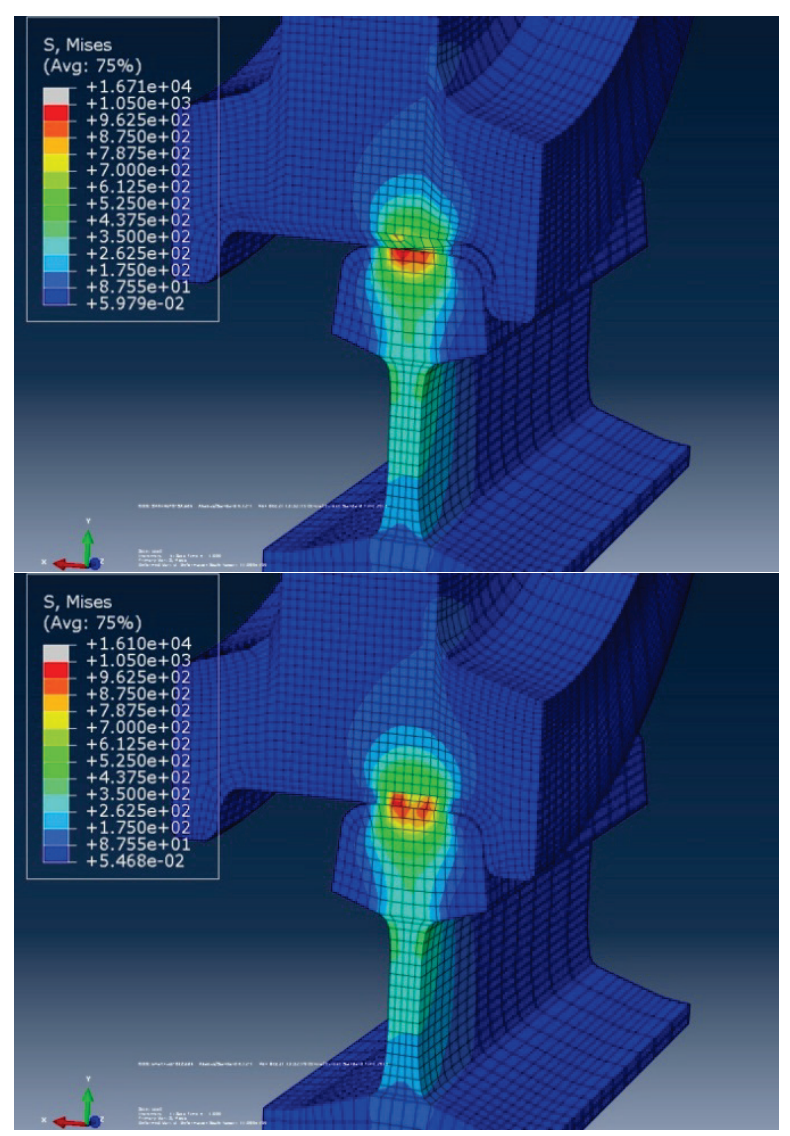

Figure 15 Upper, Von Misses stresses for asymmetric loading without a crack; Lower, Von Misses stresses for asymmetric loading with a crack

\section{Conclusion}

With the use of a welding reparation process a new layer of material has been created over the contact surface. Outer two layers have martensite structure, which is characterized by high levels of hardness and resistance to wear. Third layer ("puffer" layer) has different properties, and major role in overcoming the material properties difference between the base material of the wheel and the welded layers.

Thorough numerical simulations presented in this paper have shown that the stress field for a symmetric loading without a crack has the smallest values of stress and best distribution compared to other models. In a case of symmetric loading with a crack, an increase in the stress field can be noted. Area of the crack is positioned throughout more than $80 \%$ of the welded layer, which as a result has a significant increase in stress in the remaining $20 \%$. Presence of the crack has ensured higher deformations in the contact area, and dissipation of the stress in the base material over a larger area. Stress field dissipation can be observed throughout different sections of material in all models. In a case of asymmetric loading 
without a crack, almost identical values of stress can be observed on both wheel and the rail. Simulation of asymmetric loading with a crack has shown that a crack has a significant influence on the stress values within a welded layer of the wheel. Because of the asymmetric position, contact is achieved both on the rim and on the contact area. Crack position and size have influence on deformation, and stress dissipation over a larger area.

The crack has a significant influence on the stress field on a local level, but on a global level, if the crack is within a welded layer, integrity of the wheel will not be influenced because of material properties. As it was proven in practice, wheels with cracks located only in the martensite welded area can be further exploited, but the crack propagation should be examined and monitored. In the case of asymmetric model it was concluded that there will be no significant stress load on the rim area. Because of the specific shape of the rim and the wheel, the loading will be redirected to a contact surface and away from the rim.

Influence of the additional transversal loading on the wheel must be examined in more details since the practice has shown that a significant number of cracks can be positioned in the transition area between contact surface and the rim.

\section{Acknowledgements}

The study was carried out within the Project TP 35040, financed by the Ministry of Education, Science and Technological Development, Republic of Serbia

NOTE: This paper is based on the paper presented at the $7^{\text {th }}$ International Conference TEAM 2015 [6].

\section{References}

[1] Remennikov, A. M.; Kaewunruen, S. A review of loading conditions for railway track structures due to train and track vertical interaction. // Structural Control and Health Monitoring. 12(2008), pp. 207-234. DOI: 10.1002/stc.227

[2] Yang, Chunsheng; Létourneau, Sylvain. Learning to Predict Train Wheel Failures. // The Proceedings of the $11^{\text {th }}$ ACM SIGKDD International Conference on Knowledge Discovery and Data Mining (KDD 2005) / Chicago, USA, 2005.

[3] Popović, O.; Prokić-Cvetković, R.; Sedmak, A.; Grabulov, V.; Burzić, Z.; Rakin, M. Characterisation of high-carbon steel surface welded layer. // Strojniški vjestnik - Journal of Mechanical Engineering. 56, 5(2010), pp. 295-300.

[4] Zerbst, U.; Madler, K.; Hintze, H. Fracture mechanics in railway applications - an overview // Engineering Fracture Mechanics. 72, (2005), pp. 163-194. DOI: 10.1016/j.engfracmech.2003.11.010

[5] Lee, K. M.; Polycarpou, A. A. Wear of conventional pearlitic and improved bainitic rail steels. // Wear. 259(2005), pp. 391-399. DOI: 10.1016/j.wear.2005.02.058

[6] Tanasković, D.; Tatić, U.; Sedmak, S.; Djordjević, B.; Lozanović, J.; Sedmak, A. Integrity and life of wheels repaired by welding. $/ / 7^{\text {th }}$ International Conference TEAM 2015 , Belgrade 2015, pp. 1-6

[7] Lant, T.; Robinson, D. L.; Spafford, B.; Storesund, J. Review of weld repair procedures for low alloy steels designed to minimise the risk of future cracking. //
International Journal of Pressure Vessels and Piping. 78, (2001), pp. 813-818. DOI: 10.1016/S0308-0161(01)00094-1

[8] Arsić, D.; Lazić, V.; Aleksandrović, S.; Nikolić, R.; Marinković, P.; Đorđević, M.; Ratković, N. Theoreticalexperimental fracture analysis of responsible machine part. // Structural Integrity and Life.14, 2(2014), pp. 141-146.

[9] Marković, S.; Milović, Lj.; Marinković, A.; Lazović, T.; Tribological Aspect of Selecting Filler Metal for Repair Surfacing of Gears by Hardfacing. // Structural Integrity and Life.11, 2(2011), pp. 127-130.

[10] Čamagić, I.; Burzić, Z.; Sedmak, A.; Vasić, N.; Ćirković, B.; Algool, M. M. Influence of Mechanical Properties and Microstructural Heterogeneity of Welded Joint Constituents on Tensile Properties and Fracture Toughness at Plane Strain, KIc. // Structural Integrity and Life. 14, 1(2014), pp. 45-49.

[11] Jovičić, R.; Sedmak, S.; Tatić, U.; Lukić, U.; Walid, M. Stress state around imperfections in welded joints. // Structural Integrity and Life. 15, 1(2015), pp. 27-29.

[12] Dačić, D.; Sedmak, S.; Blačić, I.; Kirin, S. Scenario of fracture development in bucket wheel. // Structural Integrity and Life.13, 3(2013), pp. 189-198.

[13] Weldclad Roll welding technology // Material Data Sheet, Doc. No. DS024

[14] Manjgo, M.; Behmen, M.; Islamović, F.; Buzić, Z. Behaviour of Cracks in Microalloyed steel Welded Joint. // Structural Integrity and Life.10, 3(2010), pp. 235-239.

\section{Authors' addresses}

Drakče Tanasković,

Steel mill facility "Železare Smederevo"

Radinac, 11300 Smederevo, Serbia

drakcetanaskovic@gmail.com

\section{Uroš Tatić,}

Innovation Center of Faculty of Mechanical Engineering Kraljice Marije 16, 11000 Belgrade, Serbia taticuros@gmail.com

\section{Branislav Đorđević,}

Innovation Center of Faculty of Mechanical Engineering Kraljice Marije 16, 11000 Belgrade, Serbia branislav.djordjevic@kg.ac.rs

\section{Simon Sedmak,}

Innovation Center of Faculty of Mechanical Engineering Kraljice Marije 16, 11000 Belgrade, Serbia simon.sedmak@yahoo.com

\section{Aleksandar Sedmak,}

Faculty of Mechanical Engineering Kraljice Marije 16, 11000 Belgrade, Serbia asedmak@mas.bg 